\title{
The Effects of Childbirth Preparation Nursing Intervention Integrating Islamic Praying Program on Duration of Labor and Neonatal Outcomes in Primiparous Muslim Women
}

\author{
Desmawati $^{1, *}$, Waraporn KONGSUWAN ${ }^{2}$ and Warangkana CHATCHAWET ${ }^{2}$ \\ ${ }^{I}$ Department of Nursing-Midwifery, University of Pembangunan Nasional "Veteran" Jakarta, Indonesia \\ ${ }^{2}$ Faculty of Nursing, Prince of Songkla University, Songkhla 90110, Thailand
}

('Corresponding author's e-mail: desmawati.campay@gmail.com)

Received: 14 April 2018, Revised: 17 February 2019, Accepted: 19 March 2019

\begin{abstract}
Fear and anxiety in labor pain may increase the duration of labor (prolonged labor) and is one of the reasons for cesarean section in first time mothers (primiparous women). Prevention could be implemented through a childbirth preparation program with childbirth education on positioning, breathing, stroking, and Islamic praying conducted from pregnancy until labor room with family support. An experimental study design was conducted with 83 participants randomly assigned into an intervention group $(n=41)$ and control group $(n=42)$ to examine the effect of nursing interventions integrating an Islamic praying (CPNsIIIP) program on duration of active phase of labor and neonatal outcomes. The experimental group received the usual care and the program from 32 weeks of pregnancy by providing childbirth education then practice it at home every day until childbirth. In the labor room, the women recited 14 verses of the Quran, stroking, positioning during inter contractions, and just breathing during contractions of the active phase of labor at the Bhinneka Bhakti Husada Hospital and Community Health Center Pamulang, Indonesia. The control group received only the usual care. Duration of labor was measured in minutes, and neonatal outcomes were measured using the APGAR (Appearance, Pulse, Grimace, Activity, and Respiration) scale and complication of fetus after birth by collaborating with doctor. An Independent $t$ test was conducted to determine the between group effect of the program. Findings showed that duration of the active phase of labor was significantly shorter in the experimental group than in the control group after receiving the program $(t=7.51 ; p=0.00)$ and improved the neonatal outcomes, except for the APGAR scores of the babies; at 1 and $5 \mathrm{~min}$, the experimental group were $8.8 \pm 0.4$ and $8.79 \pm 0.4(p>$ $.05)$. The program in this study clearly indicated positive effects on shortening of the active phase of labor, with no complications of neonatal outcomes, in primiparous Muslim women.
\end{abstract}

Keywords: Childbirth preparation-nursing intervention program, Islamic praying, Duration of active phase of labor, Neonatal outcomes, Primiparous Muslim women

\section{Introduction}

The labor process in primiparous women is longer than in multiparous women due to slow progression in cervical dilatation before effacement [1,2]. The condition is exacerbated by fear, anxiety, physiological pain due to uterine contractions, lack of knowledge, and no experience or support from the environment. Thus, the release of catecholamines that inhibit uterine activity causes prolonged labor and fetal distress, and is a major contributor to cesarean section rates in hospitals [3-5].

Several theorists have explained the mechanisms of norepinephrine level and cortisol reduction [6] and Gate Control Theory [7] while conducting non-pharmacological interventions such as massage. Previous studies have proposed various non-pharmacological techniques to prevent prolonged labor in 
http://wjst.wu.ac.th

primiparous women including massage, family support [8], breathing [9], and upright positions [10]. However, these interventions are mostly physical. Likewise, in Indonesia, childbirth preparation for Muslim mothers in Indonesia involves mostly physical interventions, with limited spiritual interventions such as supplication $(d u a)$ and remembrance (zikr).

Therefore, the researcher developed a new holistic program for this study for normal delivery, because caesarian section is not suggested in Islam; unless there is an emergency reason for the safety of the baby and mother, birth should be conducted the natural way because, behind all the hardships of pregnancy, childbirth, and breastfeeding, there is a great blessing from God [11,12]. The need exists to develop a holistic program that involves the physical, psychological, social-traditional practice, emotional, religious, and spiritual factors in all areas of nursing that includes pregnancy to reach a short and easy delivery and good neonatal outcomes $[13,14]$.

Gate Control Theory, endorphin release, and the force of gravity are used to guide the mechanism of positioning, breathing, and stroking as physical interventions. Support from the family and childbirth education involves socio-cultural, psychosocial, and emotional interventions. Islamic praying is a spiritual belief system intervention. Islamic praying in this study is a recommended prayer. The recommendation of passive prayer, of only listening to the Quran as a non-pharmacological method, was found to be effective only for post-section caesarean and other post-operative pain [15,16], and may have some effect on the duration of labor and pain in vaginal delivery. Few studies have investigated active prayer like $d u a$ or supplication, zikr, and reciting the Quran for integration into nursing intervention to help primiparous women [17]. The spiritual factor is very important in all aspects of a patient's life [14], including during labor to find strength, a comfortable feeling, perseverance to cope with fear, tension, and pain, and make better decisions in obstetric matters [12,13]. Also, knowledge of the birth process and upright positions using the force of gravity can shorten the delivery time [17]. Support from the husband or family is needed [18] during the active phase of labor to guide women in reciting the Quran during inter-uterine contractions, help in the upright positions, and stroking. In previous studies, interventions did not use holistic care (just physical or spiritual and/or psychological care only). Implications of the Islamic praying (CPNsIIIP) program refer to a program of holistic care by giving education about labor nursing interventions (i.e., breathing, positioning, and stroking), integrated with Islamic praying (active/ruqyah prayer) and family support to reduce the duration of the active phase of labor and improve neonatal outcomes. Protocols/guidelines of the program, booklets, and health teaching were used as a reference to follow in order to ensure the stability of the program.

This study aimed to determine whether childbirth preparation nursing interventions integrating the Islamic praying (CPNsIIIP) program can reduce the length of the active phase of labor for primiparous women and improve neonatal outcomes. The hypotheses of this study were that duration of the active phase of labor in the experimental group would be shorter than the control group, that APGAR (Appearance, Pulse, Grimace, Activity, and Respiration) scores at 1 and 5 min would be normal or better than the control group, and that there would be fewer neonatal complications after birth in the experimental group than the control group. The researcher defined the duration of the active phase of labor from cervical dilation of $3-4 \mathrm{~cm}$ until the baby was born by parity control (only for primiparous women) and was singleton, with no oxytocin augmentation, and no epidural use. The program was done to prevent prolonged labor in the active phase of labor being more than $12 \mathrm{~h}$ after $\geq 3-4 \mathrm{~cm}$ of cervical dilation [19], and improve neonatal outcomes.

\section{Materials and methods}

The experimental study, with 2 groups, post-test design was conducted from June 2016 to January 2017. The sample size was calculated based on the power analysis technique with a significance level of 0.05 and a power of 0.80 , and an effect size (d) of labor pain of $1.13=10-11$ women per group and the effect size (d) of duration of labor was $0.64=31$ women per group. The sample size resulted in 82 samples for at least 41 women per group that was obtained from a previous study [20].

The eligible participants were recruited by using block randomization from the Bhinneka Bhakti Husada (BBH) Hospital and Community Health Center (CHC), Pamulang, Indonesia, which are 1st-level 
http://wjst.wu.ac.th

healthcare providers. Nurse-midwives who worked at the antenatal clinic of $\mathrm{CHC}$ and $\mathrm{BBH}$ introduced the researcher to participants who met the inclusion criteria at the antenatal clinic; the mothers were at 32 weeks of a singleton pregnancy, the mother and fetus were without complications, the mother was willing to be contacted by phone, and performed non-pharmacological labor pain exercise at home every day. The exclusion criteria were the development of any adverse medical disease, psychological depression, pregnancy complications such as preeclampsia, heart, renal, or thyroid disease, placental abruption, asthma, placenta previa, twin pregnancy, and any possibility of fetal anomaly like fetal distress, hydrocephalus, coming late to the labor room (more than $4 \mathrm{~cm}$ of cervical dilation), and not completing the program.

Signed informed consent was obtained from the 83 pregnant women before interventions were initiated. The Institutional Review Board (IRB) of the Faculty of Nursing, Prince of Songkla University, Thailand (code: MOE 0521.1.05/1663), and the Ethics Committee from Bhinneka Bhakti Husada Hospital, Jakarta, Indonesia, approved this study.

\section{Data collection}

In the antenatal clinic, the primiparous primigravida women completed a Demographic Data Questionnaire (DDQ). The DDQ was developed by the researchers, and consisted of age of mother, ethnic, education level, and family member accompanying the women. An Obstetric Data Questionnaire (ODQ) was used to measure the obstetric data at the antenatal care and labor room, which was also developed by the researchers. In order to maintain the stability of the content of the material presented to all women, only the researcher gave health education to women at the antenatal clinic.

The researchers provided a booklet regarding childbirth preparation (i.e., breathing, stroking, positioning, and Islamic praying/ruqyah or active prayer). This booklet was made by the researchers by consulting with 2 experts in Islamic knowledge and 5 experts in the maternity nursing area. Every participant followed this booklet as a guideline to perform the program. The conceptual frameworks of this study were underpinned by Islamic Philosophy, Holistic Nursing Theory, and Labor Support.

Pillar number 2 (prayer) of the 5 Fundamental Pillars of Islam especially recommends prayer and faith to scriptures (Qur'an) of 6 of true faiths underlying this study. The researcher selected 14 verses of prayer $\left(d u^{\prime} a\right)$ from the Quran relating to pregnant women and childbirth, which are spread in different juz and surah in the Qur'an. Islam has rules and guidelines that are comprehensive or holistic, harmonious, perfect, clear, and logical that govern all aspects of life (QS Al-Maidah 5: 3; Al-Baqarah 2: 21 - 25; AnNahl 16: 89). Islamic philosophy is not only beneficial to spiritual and cultural health, but also physical and psychological health. Truly, man is not given the better things in the world, except a heart is convinced and calm, and then physical health, thus asking both to Allah (Hadits; Ahmad). Islamic philosophy has always suggested the human being make good relationships and respect the cultural beliefs of other people in giving or doing something.

Holistic nursing congruent with Islamic philosophy is planned to meet the needs of the whole person to improve health and increase the healing of the whole person; physical, psychological, socio-cultural, and spiritual. Holistic Nursing: a Handbook for Practice by Dossey (2013) is also integrated with culture and religion or belief systems (not only physical treatment) and praying as a good method for healing pain [21]. Likewise, labor support also aims to meet the physical, psychological, informational, socio-cultural, spiritual, and emotional needs of women during childbirth [22]. Mechanisms of Islamic prayer, breathing, and stroking guiding by Gate Control Theory (GCT), and positioning guiding by gravity/force, allows the reaching of the outcomes of this research.

\section{Procedure of the program}

The procedures of the program were conducted at the antenatal clinic and labor room. At the antenatal clinic, the primiparous primigravida women in the experimental group received childbirth education on non-pharmacological pain management (i.e., breathing, stroking, positioning, and Islamic praying/ruqyah or active prayer) by face to face for around 30 - $60 \mathrm{~min}$. Content validity Index (CVI) of the program was 0.83 . The researcher then suggested that the women practice these nursing interventions 
http://wjst.wu.ac.th

at home at least once every day until entering the delivery room. To prevent bias, the women were asked not to show or discuss the booklet to any other person until the program had finished.

For the next process, the time of data collection was conducted at the delivery room in the active phase of labor. The inclusion criteria at the labor room for the mother and fetus included: (1) normal gestation for birth; (2) normal fetal heart rate (120 - 160 beats/min) assessed using a Doppler stethoscope; (3) latent phase of no more than $12 \mathrm{~h}$; (4) cephalic presentation (occiput posterior); (5) arrive at the labor room at $3-4 \mathrm{~cm}$ of cervical dilatation; (6) progress of labor and delivery of not less than $3 \mathrm{~h}$; (7) no health complications of the mother or fetus; and (8) labor support from the family. Participation was terminated if participants arrived at the labor room at $>4 \mathrm{~cm}$ of cervical dilatation, latent phase $>12 \mathrm{~h}$, the labor process was more than $3 \mathrm{~h}$ from $3-4 \mathrm{~cm}$ of cervical dilation, or not all sessions of the program were joined.

The researcher or research assistants used a wall clock to measure the starting point of the active phase of labor when cervical dilation was $3-4 \mathrm{~cm}$. The process of the program at the labor room was as follows; the women took about $30 \mathrm{~min}$ to perform the recommended ruqyah/active prayer by reciting 14 verses of the Quran regarding how human beings were created by God: 1) name of Quran sureh AlMukminun 23: number 12 - 14 (Allah created man from an extract of clay (because food comes from the ground), Allah formed the fetus from sperm and it was placed in the womb, Allah changed the sperm into a clot of congealed blood, then that clot became a fetus lump, which was then wrapped by bones, and then wrapped with flesh, then Allah developed creation so it become human. Allah is the Best Creators); 2) name of Quran sureh As-Sajdah 32: number 9 (Allah fashioned the fetus in due proportion and breathed into the fetus of His spirit. And Allah gave you the hearing, sight, and understanding); 3) name of Quran sureh Al-Hijr 15: number 29 has the same meaning with the name of Quran sureh Shad 38: number 72 (when Allah have fashioned him in due proportion and breathed into him of my spirit, fall ye down in obeisance and prostration unto him); 4) name of Quran sureh Al-Imran 3: number 6 (He it is who shapes you in the wombs as he pleases, there is no God but Allah); 5) name of Quran sureh Al-A'raf 7: number 172 (and made them testify concerning themselves, saying; Am I not your Lord who cheriches and sustains you? they said; yes, we do testify!...); 6) name of Quran sureh Al-Qiyamah 75: number 39 (Allah made 2 sexes, male and/or female); 7) name of Quran sureh Al-Fathir 35: number 11 (Then Allah made you in pairs. No female gets pregnant and goes through childbirth, except with Allah's knowledge); 8) name of Quran sureh Ar-Ra'd 13; number 8 (Allah doth know what was conceived by every woman, what is less than perfect or disabled and what is growing in the womb); 9) name of Quran sureh AlFurqan 25: number 54 (Allah established the relationships of lineage and marriage); 10) name of Quran sureh Az-Zumar 39: number 6 (Allah creates you in your mother's womb, within three stages (three trimesters); 11) name of Quran sureh Al-Imran 3: number 36 (Allah was most knowing of what is in the uterus and what is born by pregnant women); 12) name of Quran sureh Ibrahim 14: number 40 (O Allah, grant us and our wives and offspring as comforter to our eyes and make us an example for the righteous. O Allah, make me and my descendants always perform/ establish the prayer, and please accept my prayer); 13) name of Quran sureh Abasa 80: number 20 (Then Allah eases the way for the infant birth (Allah makes ease during childbirth), and 14) name of Quran sureh An-Nahl 16: number 78 (Allah brought you forth from the wombs of your mother when you know nothing, and then Allah gave you hearing, sight, intelligence, and affections that perhaps you would be grateful). These verses were read by the primiparous women from the paper; they was no memorization of the recitation. After that, stroking was conducted on the abdomen (fundus uterine) using the "love" pattern by the mother or the family. The nursing interventions were equivalent to the basic steps of ruqyah prayer, because reciting verses of the Quran is done for healing by touching the sick area. In Indonesia, this is called ruqyah syariah. The ruqyah syariah is done by reciting the verses of the Qur'an which helps pregnant women perform active prayer, because the women recite the Qur'an by themselves to contemplate and, in the end, surrender themselves to God by saying "laa hawla walaa quwwata illah billah" (tawakkal 'alallah). These interventions were conducted during inter-uterine contractions, whereas during uterine contractions, the women did the breathing only. Families helped to set the mother in upright positions like squatting, standing, sitting, and walking if the amnion membrane had not ruptured, and upright positions on the bed like sitting and semi-sitting if the amnion membrane had ruptured. Positioning and stroking were done as 
http://wjst.wu.ac.th

much as the women could. Integration between positioning, breathing, Islamic praying, and stroking was performed 3 times at the 1st, 2nd, and 3rd hour after cervical dilation of $3-4 \mathrm{~cm}$ with labor support from their families. To avoid contamination between the groups, separate delivery rooms were used.

The women who were in the control group only received the usual care based on the guidelines from $\mathrm{BBH}$ and $\mathrm{CHC}$ Pamulang, including regular check-ups at least twice in 3rd trimester of pregnancy; they received general health education if the women were in the referral order. Nursing intervention at the labor room included monitoring of vital signs and a vaginal examination to monitor dilation of the cervix, deflation in the head of fetus, and color of amniotic fluid during the 1st stage of labor, and also used the 58 steps of Normal Delivery Care from the Indonesian Health Ministry. The duration of the active phase of labor was measured in minutes after dilation reached $10 \mathrm{~cm}$. The APGAR scores were measured at 1 and 5 min after birth. Neonatal complications were measured when the termination phase was completed $2 \mathrm{~h}$ after the baby was born by collaborating with the doctors. After dropouts and outliers were deleted, the sample size in this study was 83 women: 41 in the experimental group and 42 in the control group.

\section{Data analysis}

Data were analyzed using SPSS (v. 21; IBM, USA). Descriptive statistics were used to analyze the DDQ and ODQ. Chi-square, Fisher's exact test, and Independent $t$-test were used to examine the difference of characteristics between both groups at the baseline. The assumption of normality and homogeneity of variance of the variables had been conducted before determining the appropriate statistical analysis. Assumptions for the independent $t$-test of all participants in the experimental and the control groups were met after the outliers were deleted. The data were in a normal distribution and the data of both groups were similar. Normal distribution of duration of labor; Skewness value $=1.57$, kurtosis value $=0.10$, and no outlier (box plot). The researchers used the Independent $t$-test for testing the differences of mean scores of the duration of labor and APGAR score between the experimental and control groups after receiving the program. Chi-square was also used to test difference of neonatal complications after birth between the experimental and control groups after receiving the program.

\section{Result and discussion}

\section{Demographic data}

There was no significance difference in demographic data between the experimental group and the control group. The baseline demographic data of both groups were similar.

Table 1 Demographic data.

\begin{tabular}{|c|c|c|c|c|}
\hline \multirow[t]{2}{*}{ Variables } & $\begin{array}{l}\text { Experimental group } \\
\qquad(n=41)\end{array}$ & $\begin{array}{l}\text { Control group } \\
\quad(n=42)\end{array}$ & \multirow[t]{2}{*}{$t / X^{2}$} & \multirow[t]{2}{*}{$p$} \\
\hline & $n(\%)$ & $n(\%)$ & & \\
\hline Age (years) & $\begin{array}{c}23.4(2.9) \\
M(S D)\end{array}$ & $\begin{array}{c}23.14(3.7) \\
M(S D)\end{array}$ & -0.24 & 0.732 \\
\hline \multicolumn{5}{|l|}{ Ethnicity } \\
\hline $\begin{array}{l}\text { Betawinese, Sundanese } \\
\text { Javanese, Minang, Batak }\end{array}$ & $\begin{array}{l}31(75.6) \\
10(24.4)\end{array}$ & $\begin{array}{l}33(78.6) \\
9(21.4)\end{array}$ & 0.10 & 0.748 \\
\hline \multicolumn{5}{|l|}{ Educational level } \\
\hline $\begin{array}{l}\text { Senior and junior high school } \\
\text { Diploma and bachelor }\end{array}$ & $\begin{array}{l}34(82.9) \\
7(17.1)\end{array}$ & $\begin{array}{l}35(83.3) \\
7(16.7)\end{array}$ & 0.00 & 0.961 \\
\hline \multicolumn{5}{|l|}{ Occupation } \\
\hline $\begin{array}{l}\text { Not working } \\
\text { Working }\end{array}$ & $\begin{array}{c}34(82.9) \\
7(17.1)\end{array}$ & $\begin{array}{l}31(73.8) \\
11(26.2)\end{array}$ & 1.02 & 0.314 \\
\hline Family's income per month (IDR) & $\begin{array}{c}4,182.92(1,808.85) \\
M(S D)\end{array}$ & $\begin{array}{c}3,809.52(1,909.38) \\
M(S D)\end{array}$ & -0.69 & 0.363 \\
\hline
\end{tabular}


http://wjst.wu.ac.th

\section{Obstetric data}

There was no significance difference between the experimental group and the control group at the baseline of the obstetric data.

Table 2 Obstetric data.

\begin{tabular}{|c|c|c|c|c|}
\hline \multirow[t]{2}{*}{ Characteristics } & $\begin{array}{l}\text { Experimental } \\
\text { Group }(n=41)\end{array}$ & $\begin{array}{c}\text { Control Group } \\
(n=42)\end{array}$ & \multirow[t]{2}{*}{$t / \mathbf{X}^{2}$} & \multirow[t]{2}{*}{$p$} \\
\hline & n $(\%)$ & n (\%) & & \\
\hline Amount of time receiving ANC & $\begin{array}{c}10.3(2.1) \\
M(S D)\end{array}$ & $\begin{array}{c}10.2(1.8) \\
M(S D)\end{array}$ & -0.41 & 0.678 \\
\hline Painful menstruation* & & & & \\
\hline $\begin{array}{l}\text { No } \\
\text { Yes }\end{array}$ & $\begin{array}{l}39(95.1) \\
2(4.9)\end{array}$ & $\begin{array}{c}38(90.5) \\
4(9.5)\end{array}$ & 0.16 & 0.694 \\
\hline $\begin{array}{l}\text { Age of pregnancy at health } \\
\text { teaching }\end{array}$ & $\begin{array}{l}32.6(0.4) \\
M(S D)\end{array}$ & $\begin{array}{l}32.7(0.4) \\
M(S D)\end{array}$ & 1.01 & 0.316 \\
\hline $\begin{array}{l}\text { Family support at ANC } \\
\text { Mother }\end{array}$ & $5(12.2)$ & $5(11.9)$ & & \\
\hline $\begin{array}{l}\text { Husband } \\
\text { Female relative or } \\
\text { Other }\end{array}$ & $\begin{array}{l}23(56.1) \\
13(31.7)\end{array}$ & $\begin{array}{c}32(76.2) \\
5(11.9)\end{array}$ & 5.02 & 0.081 \\
\hline Family support at labor & & & & \\
\hline $\begin{array}{l}\text { Mother } \\
\text { Husband }\end{array}$ & $\begin{array}{l}19(46.3) \\
22(53.7)\end{array}$ & $\begin{array}{l}24(57.1) \\
18(42.9)\end{array}$ & 0.97 & 0.325 \\
\hline Gestational age at birth & $\begin{array}{c}39.3(0.9) \\
M(S D)\end{array}$ & $\begin{array}{c}39.2(0.9) \\
M(S D)\end{array}$ & -0.76 & 0.446 \\
\hline Mother's weight & $\begin{array}{c}69(5) \\
M(S D)\end{array}$ & $\begin{array}{c}68(6) \\
M(S D)\end{array}$ & -0.52 & 0.602 \\
\hline Mother's height & $\begin{array}{c}153.6(3.8) \\
M(S D)\end{array}$ & $\begin{array}{c}153.7(3.2) \\
M(S D)\end{array}$ & 0.13 & 0.892 \\
\hline $\begin{array}{l}\text { Ruptured membrane } \\
\text { No } \\
\text { Yes }\end{array}$ & $\begin{array}{c}8(19.5) \\
33(80.5)\end{array}$ & $\begin{array}{c}8(19) \\
34(81)\end{array}$ & 0.00 & 0.957 \\
\hline $\begin{array}{l}\text { Receiving artificial rupture of } \\
\text { membrane } \\
\text { No } \\
\text { Yes }\end{array}$ & $\begin{array}{l}33(80.5) \\
8(19.5)\end{array}$ & $\begin{array}{l}34(81) \\
8(19)\end{array}$ & 0.00 & 0.957 \\
\hline $\begin{array}{l}\text { Characteristics of amniotic fluid } \\
\text { Clear } \\
\text { Mild-Thick }\end{array}$ & $\begin{array}{l}31(75.6) \\
10(24.4)\end{array}$ & $\begin{array}{l}27(64.3) \\
15(35.7)\end{array}$ & 1.26 & 0.261 \\
\hline
\end{tabular}

Hypothesis 1: Effect of childbirth preparation nursing intervention integrating Islamic praying on shortening duration of active phase of labor in primiparous Muslim women.

The mean score of duration of labor (in minutes) in the active phase of labor in the experimental group was shorter. In relation to the time spent in the active phase of labor (from 3 or $4 \mathrm{~cm}$ to $10 \mathrm{~cm}$ of cervical dilatation), the total mean time in the active phase of the 1st stage of labor of the experimental group was $202.3 \mathrm{~min}(\mathrm{SD}=41.2)$ (range 180 to $330 \mathrm{~min}$ ). The mean score of time spent in the active phase of labor in the control group was $313.8 \mathrm{~min}(\mathrm{SD}=86.6)$ (range 180 to $540 \mathrm{~min})$. Table 3 shows the 
http://wjst.wu.ac.th

mean scores of the duration of the active phase of labor between the experimental and the control group after receiving the program. Independent $t$-test suggested there was statistical significance in the active phase of labor $(p<0.001)$

Table 3 Comparisons of Mean Scores and Standard Deviations of Duration of Active Phase of Labor between the 2 Groups $(n=83)$ using Independent $t$-test.

\begin{tabular}{|c|c|c|c|c|c|c|}
\hline \multirow[t]{2}{*}{ Phases of labor } & \multicolumn{2}{|c|}{$\begin{array}{c}\text { Experimental } \\
\text { Group } \\
(n=41)\end{array}$} & \multicolumn{2}{|c|}{$\begin{array}{c}\text { Control } \\
\text { Group } \\
(n=42)\end{array}$} & \multirow[t]{2}{*}{$t$} & \multirow[t]{2}{*}{ p-value } \\
\hline & $\mathbf{M}$ & SD & $\mathbf{M}$ & SD & & \\
\hline $\begin{array}{l}\text { Active phase ( } 3-4 \text { to } 10 \mathrm{~cm} \text { of } \\
\text { cervical dilation) }\end{array}$ & 202.3 & 41.2 & 313.8 & 86.6 & 7.51 & 0.00 \\
\hline
\end{tabular}

$\mathrm{M}=$ mean score, $\mathrm{SD}=$ standard deviation

Hypothesis 2: Effect of childbirth preparation nursing intervention integrating Islamic praying on neonatal outcomes (APGAR Score and neonatal complications after birth) in primiparous Muslim women

Means and standard deviations of APGAR scores of the babies in the experimental group and control group taken at $1 \mathrm{~min}$ were $8.8 \pm 0.4$ and $8.79 \pm 0.4$, respectively. The mean APGAR scores of the babies in the experimental group and control group taken at 5 min were $9.8 \pm 0.4$ and $9.79 \pm 0.4$, respectively. There were no significant differences between the groups $(p>0.05)$ (Table 4).

Table 4 Means and Standard Deviations of APGAR score in Experimental and Control Group $(n=83)$.

\begin{tabular}{|c|c|c|c|c|}
\hline \multirow[t]{2}{*}{ APGAR scores } & $\begin{array}{l}\text { Experimental } \\
\text { group }(n=41)\end{array}$ & $\begin{array}{l}\text { Control group } \\
\quad(n=42)\end{array}$ & \multirow[t]{2}{*}{$t$-test } & \multirow[t]{2}{*}{$p$-value } \\
\hline & $n(\%)$ & $n(\%)$ & & \\
\hline APGAR score $1 \mathrm{~min}$ & $\begin{array}{c}8.8(0.45) \\
M(S D)\end{array}$ & $\begin{array}{c}8.79(0.41) \\
M(S D)\end{array}$ & -0.19 & 0.84 \\
\hline APGAR score 5 min & $\begin{array}{c}9.8(0.45) \\
M(S D)\end{array}$ & $\begin{array}{c}9.76(0.43) \\
\mathrm{M}(\mathrm{SD})\end{array}$ & -0.43 & 0.66 \\
\hline
\end{tabular}

Table 5 shows the comparison of neonatal complications after birth between the experimental group and control group. The results showed there was a statistically significant difference between the experimental and control group $(p<0.05)$.

Table 5 Frequencies and Percentages of Neonatal Complications After Birth in Experimental Group and Control Group $(n=83)$.

\begin{tabular}{|c|c|c|c|c|}
\hline \multirow{2}{*}{$\begin{array}{c}\text { Neonatal complications } \\
\text { after baby birth }\end{array}$} & $\begin{array}{l}\text { Experimental } \\
\text { group }(n=41)\end{array}$ & $\begin{array}{c}\text { Control group } \\
(n=42)\end{array}$ & \multirow[t]{2}{*}{$\mathbf{x}^{2}$} & \multirow[t]{2}{*}{$p$} \\
\hline & $n(\%)$ & $n(\%)$ & & \\
\hline No & $41(53.2)$ & $36(46.3)$ & 4.36 & $0.037 *$ \\
\hline Yes & $0(0)$ & $6(14.3)$ & & \\
\hline
\end{tabular}




\section{Discussion}

There were significant differences in duration of the active phase of labor between the experimental and control groups after they received the program. Duration of the active phase of labor in the experimental group was $202.31 \mathrm{~min}(\mathrm{SD}=44.23)$ and $313.76 \mathrm{~min}(\mathrm{SD}=86.56)$ in the control group. The program shortened the duration of the active phase of labor. It showed the opposite results for the control group. Another study reported a similar mean labor duration of the active phase of labor for primiparous women that was $8.22 \mathrm{~h}$ or $493.2 \mathrm{~min}(\mathrm{SD}=4.36 \mathrm{~h})$ without any interventions [23].

There are very few studies on the effect of childbirth preparation nursing intervention integrating Islamic praying on duration of labor. However, some studies have reported a significant effect on duration of labor by passive praying of only listening to 78 verses of QS Ar-Rahman for $1.5 \mathrm{~h}$ during childbirth [16]. The findings of the current study are that using 14 verses of the Qur'an can distract, which causes the brain to project directly to close the gate and inhibit the ascending of nociceptor to the brain, thus relieving discomfort and shortening duration.

These results are similar to another randomized controlled trial which used massage as the nonpharmacological intervention to shorten the duration of labor at the active phase and the 2 nd stage of labor and improve the APGAR scores at 1 and $5 \mathrm{~min}$ [24,25]. Massage with essential oils for about 30 min at each stage of labor with controlled breathing and position or movement benefited pain relief and lowered the duration of the active phase of labor [26]. Breathing was one of the ways to manage uterine contractions [9]. The duration of labor can be shortened when amniotomy is done and uterine contractions are effective and strong [27]. In the 1st stage of labor, breathing was used to increase abdominal pressure which assisted in expelling the fetus and relaxed the pudendal muscles to prevent precipitate expulsion of the fetal head, which resulted in pain relief and shorter labor duration [28].

Moreover, gravity positioning (i.e., upright positions) and mobilization increased the natural levels of oxytocin circulation in the blood and uterine contractions worked effectively, resulting in a shorter delivery time [10]. Support and gravity, or upright positions, during labor can promote the descent of the fetus and make uterine contractions stronger and more efficient in effacing and dilating the cervix, which results in a shorter duration of the active phase of labor [28-30]. Consistent with a previous study, patients who were immobilized in the supine position had lower natural levels of oxytocin in the blood, the uterine contractions were worse and more painful and, without gravity assistance, the delivery time was extended [30]. In the current study, used upright positions (standing, walking, squatting, sitting) can shorten duration of labor by force and gravity. When a primiparous woman is in upright positions, there is less risk of compressing her aorta, which results in better oxygen supply to the baby. Force and gravity helps the uterus to contract more strongly and efficiently and makes the fetus move into a better position to pass through the pelvis. The descent of the fetus makes uterine contractions stronger and more efficient in effacing and dilating the cervix and results in shortening the duration of the active phase of labor and bringing the baby down and out. It appears the upright position is recommended to prevent prolonged labor and shorten the duration of labor.

It appears the results of this study were supported by the earlier studies; however, the existing studies were not holistic in nature. Breathing in this program increased the blood flow, which then improved $\mathrm{O}_{2}$ saturation, and stroking could increase the level of endorphins and stimulate large nerve endings and close the gate. Therefore, calming the mother can reduce pain and shorten the duration of labor. Focusing on one point (in this study, God) while praying caused neuron A (myelinated) messages to reach the brain more rapidly than pain messages to close the gate to pain messages, whereas the pain signal is carried more slowly by neuron $C$ fibers (unmyelinated) [31,32]. When a primiparous woman is in the upright position, there is less risk of compressing her aorta, which results in better oxygen supply to the baby [32]. The force of gravity helps the uterus contract more strongly and efficiently and helps the fetus get into a better position to pass through the pelvis. The descent of the fetus causes uterine contractions to be stronger and more efficient in effacing and dilating the cervix which results in a shorter duration of the active phase of labor and bringing the baby down and out $[30,32]$. The use of holistic care in this study by physio-psychological (i.e., breathing, positioning, stroking), sociocultural (i.e., labor support from the family), and spiritual (i.e., ruqyah/active prayer) factors helped the mother during 
pregnancy and birth. Also, the holistic care provided harmony of the body, mind, and spirit. Health in all aspects (i.e., physical, psychological, emotional, social, and cultural) will occur when spiritual health has already formed (Hadist; Ahmad).

In this case, the mothers believed that the process of creating a human being from the womb until birth and death is simply the power of God (the creator). Islam suggests thinking about Allah's creations, such as the sky, sun, stars, earth, mountains, sea, air, land, people, animals, plants, etc., and not thinking about Allah's substance or Allah's matter (Hadist R Ahmad \& At-Thabrani). Just because you cannot see the air, does not mean you stop breathing. Just because you cannot see Allah, does not mean you stop believing. And on the earth are the signs of Allah's greatness for those of assured faith, as also in your own selves. Will you not see? (QS Az-Dzariyat, 51: 20 - 21). Remember for all human being! Your agreement with Allah when in the womb at 16 - 18 weeks of pregnancy, "When Allah drew forth from the children of Adam from their descendants, and made them testify concerning themselves, (saying): "Am I not your Lord/God (who cherishes and sustains you)?" "They said: Yes! We do testify!" this, lest you should say on the day of judgment: "Of this we were never mindful" (QS Al-A'raf, 7: 172).

Praying in Islam is a realization from tauhid behaviors inducing good moral ethics, positive thinking to Allah, and decreasing arrogance (QS Ghafir: 60). Active praying is the harmony between heart, mind, speech, and action (blend of intent, planning, statement, and action). Active praying requires attitude wisdom, inner meticulousness, patience, and fortitude; not dictating to Allah, good prejudice to Allah, and surrendering oneself on Allah by saying "Laahaulawala quwwata illa billahil 'aliyul adziim” (A person still cannot do anything without the help of Allah). The prophet Muhammad, peace be upon him, said, "Whoever reads it, an angel descends to give good health/brings a cure for that person" (Hadist R Tirmizi). Another says "if recited one will be protected from 70 afflictions/hardships/difficulties in life, even a disease, and protected from punishments/afflictions/suffering (Hadist Mafhoom ul hadith).

These findings indicated that surrendering oneself to Allah is considered as a strong factor leading to birthing smoothly. In Taisirul Azizul Hamidh 503, Ibnul Qayyim said "Allah sufficient to those who put their convinced in him. Allah gives peace from fear. Allah is the best protector and the best helper and whoever takes refuge in him and asks for help from him and puts their trust in him, Allah will protect them, guard them, and anyone who fears Allah, Allah will make them comfortable and calm down from something, include during labor, thus the women have childbirth easily.

Behind all the hardships of pregnancy, childbirth, and breastfeeding, God will give wisdom and promises great rewards for mothers who struggled against pain to have an easy childbirth [12]. Thus, understanding the spirituality of the practice of holistic care is very important for a smooth birth. Even though dilatation in active labor varies widely among women and is significantly influenced by several physical and psychological factors, such as parity, fear, anxiety, stress, maternal weight, and fetal weight $[17,23,33]$, prayer in this study has a positive relationship with physical health, allowing an easy delivery. Prayer therapy brings spiritual benefits first, and then the physical becomes healthy by increasing harmoniousness and happiness in life. Truly, man is not given the better thing in the world, except a soul is convinced and calm, and then physical health, as in Hadith Bukhari (from Nu'man bin Bashir said: I heard the prophet Muhammad said: in the body there is a plume of flesh, if it is good, the body will be good, and vice versa if it is bad then the body will be bad, Know the lump of meat is "Qolbu or soul"); thus, in a healthy soul, there is strong physical health, and vice versa. The role of the nurse is to assist the patients to fulfill holistic ends, and spiritual development is more important than physical care only.

Providing knowledge on the birth process, active prayer, positioning, breathing, and stroking with family support in this study caused the women to have no fear, no anxiety, and lower labor pain, and the uterine contractions were effective, preventing prolonged labor, shortening the duration of labor, and improving neonatal outcomes. Also, psychosocial support by a female companion had a significant effect on duration of labor [8]. Women who were accompanied by family, mother, husband, or female relatives during labor were buffered against stressors, which shortened their labor [29]. Labor support (doula from family members) could also reduce the time of labor [34].

In this study, family support had influence to improve confidence in primiparous women. The role of family member who supported the women was to remind them to perform exercise every day at home, at least 30 min per day, from 32 weeks of pregnancy until labor, and accompany women to do breathing, 
positioning, praying, and stroking together at the labor room. Similarly, a previous study revealed that, to achieve behavioral change, primiparous women needed family support and health care professionals [35].

Moreover, follow-up by telephone every day and face to face more than once could maintain positive behaviors. These results were the same as an early study reporting that intervention using phone calls and face to face follow-up were effective in improving self-management behaviors such as physical exercise [36].

The results of the APGAR scores of the previous study reported that listening to the Quran could increase an infant's APGAR score [16]. However, in this study, there was no significant difference between the experimental and control group after receiving the program. The APGAR scores of the infants at 1 and $5 \mathrm{~min}$ had similar improvement in both the experimental and control groups, because the length of time in labor in the control group was not included in the prolonged labor category (still normal). This was similar to a previous study which reported that women who have prolonged labor can decrease APGAR scores at 1 and $5 \mathrm{~min}$ because a long delivery time increases fetal distress, leading to low APGAR scores [37]. Another study showed that about $90 \%$ of infant APGAR scores were good at 1 min, and all infants had good APGAR scores after they received massage and positioning [20].

There were no complications of the fetus after birth, such as asphyxia, pathologic icterus/jaundice, sepsis, seizures, etc., in the experimental group in this study, maybe due to the application of breathing, Islamic praying, and positioning. These interventions could improve the mother and baby's oxygenation in their daily lives to prevent lack of oxygen during and after birth. These results were consistent with a previous study that explained that the mechanism of regular physical activity, such as positioning and breathing, could improve oxygen consumption and increase the functioning of the cardiovascular and respiratory systems of the mother, attenuation of gestational diabetes mellitus, preeclampsia, dyspnea, etc. Also, it could a improve neonatal outcomes such as preventing neonatal hypoxia, decreasing fat mass, improving stress tolerance, advancing neurobehavioral maturation, etc. Even physical activity can shorten labor and decrease incidence of caesarean section [38].

This study is not without limitations. First, the researcher was unable to control the sleep factors of women during pregnancy and the ages of the mothers. Second, the program could not control incidences of women who artificially and intentionally ruptured the amniotic membranes (amniotomy) with incidences of women who had spontaneous rupture of the amniotic membranes. An amniotomy significantly speeds up uterine contractions and shortens the duration of labor [26,39]. Third, the results of this study cannot be generalized to multiparous women, because the progress of labor in multiparous women is faster than in primiparous women. Fourth, this program was conducted only in the active phase of labor; therefore, it could not shorten the duration of labor in the 2 nd stage of labor. Fifth, the researcher could not determine which one of the upright positions could significantly cause a shorter duration of labor.

Therefore, the recommendations for future studies of a similar intervention must consider these factors: 1) the need to control the sleep factors of women during pregnancy and the mother's age; 2) the need to separate amniotomy from spontaneous rupture of membranes; 3) to conduct the program only once for multiparous women with normal vaginal delivery and in the event of twins pregnancy and high risk women with normal labor; 4) to continue to conduct the program until the baby is born, even into the 3rd stages of labor; 5) the need for high quality trials to compare between the types of upright positions (e.g., sitting upright vs. walking).

\section{Conclusions}

Childbirth preparation nursing interventions integrating Islamic praying program is culturally fit for Muslim women in Indonesia. Providing childbirth education on positioning, breathing, and stroking which is integrated with Islamic praying (i.e., ruqyah in active prayer) in the antenatal clinic and is practiced in the labor room can promote a shorter duration of the active phase of labor and improve neonatal outcomes. Prayer holds an important role in life and becomes more important during pregnancy and giving birth. It is suggested that this program be continuously given to primiparous women in all maternity settings, and regularly from pregnancy until birth, because the program is effective. Further 
http://wjst.wu.ac.th

investigations are highly recommended in more diverse Muslim, and even non-Muslim, women in other countries.

\section{Acknowledgements}

The authors are extremely grateful to the primiparous women and their families who participated in this study. Appreciation is expressed for funding from the Graduate School, Prince of Songkla University, and University of Pembangunan Nasional Veteran Jakarta.

\section{References}

[1] G Capogna, M Camorcia, S Stirparo, G Valentini, A Garassino and A Farcomeni. Multidimensional evaluation of pain during early and late labor: A comparison of primiparous and multiparous women. Int. J. Obstet. Anesth. 2010; 19, 167-70.

[2] I Shrestha, N Pradhan and J Sharma. Factors influencing perception of labor pain among parturient women at Tribhuvan University Teaching Hospital. Nepal Obstet. Gynecol. 2013; 8, 26-30.

[3] N El-Wahab and N Robinson. Analgesia and anaaesthesia in labor. Obstet. Gynec. Reprod. Med. 2014; 24, 97-102.

[4] F Rakers, S Bischoff, R Schiffnes, M Haase, S Rupprecht, M Kiehntopf, N Kuhn-Velten, H Schubert, OW Witte, MJ Nijland, PW Nathanielsz and M Schwab. Role of catecholamines in maternal-fetal stress transfer in sheep. Amsterdam J. Obstet. Gynecol. 2015; 213, 684.e1-684.e9.

[5] EA Torkildzen, KA Salvesen and TM Eggebo. Prediction of delivery mode with transperineal ultrasound in women with prolonged 1st stage of labor. Ultrasound Obstet. Gynecol. 2011; 37, 7028.

[6] T Field. Pregnancy and labor massage. Expert Rev. Obstet. Gynecol. 2010; 5, 177-81.

[7] R Melzack and PD Wall. Pain mechanism: A new theory. Science 1965; 150, 971-9.

[8] TT Samieizadeh, M Sereshti, AR Dashipur, N Mohammadinia and A Arzani. The effect of supportive companionship on length of labor and desire to breastfeed in primiparous women. $J$. Urmia Nurs. Midwifery Fac. 2011; 4, 262-9.

[9] JA Lothian. Lamaze breathing: what every pregnant woman needs to know. J. Perinat. Educ. 2011; 20, 118-20.

[10] S Gizzo, SD Gangi, M Noventa, V Bacile, A Zambon and GB Nardelli. Women's choice of positions during labor: Return to the past or a modern way to give birth? A cohort study in Italy. Biomed. Res. Int. 2014; 2014, 1-7.

[11] LC Callister and I Khalaf. Spirituality in childbearing women. J. Perinat. Educ. 2010; 19, 16-7.

[12] R Say, S Robson and R Thomson. Helping pregnant women make better decisions: A systematic review of the benefits of patient decision aids in obstetrics. BMJ Open 2011; 1, 1-15.

[13] BM Dossey and L Keegan. Holistic Nursing: A Handbook for Practice. $6^{\text {th }}$ ed. Jones \& Bartlett, Burlington, 2013, p. 6.

[14] D Yilmas, S Kisa, S Zeyneloglu and T Guner. Determination of the use of traditional practices to ease labor among Turkish women. Int. J. Nurs. Pract. 2013; 19, 65-73.

[15] AM Abbas, AA El-Houfey, AY Abdelbadee, MK Ali, SS Ali, RM Abdelrahman and SM Tolba. Effects of listening to Qur'an on maternal \& neonatal outcomes among mothers undergoes cesarean section. Int. J. Nurs. Midwife Health Related Cases 2016; 2, 39-53.

[16] R Bayrami and H Ebrahimipour. Effect of the Quran sound on labor pain and other maternal and neonatal factors in primiparous women. J. Res. Health 2014; 4, 898-902.

[17] VI Yuel, V Kaur and D Kaur, Programmed labor for optimizing labor and delivery. Science 2008; 10, 62-4.

[18] B Hastuti. Effect husband support on duration of labor in primiparous. Humanitas 2009; 6, 123-34.

[19] JL Neal, NK Lowe, TE Patrick, LA Cabbage and EJ Corwin. What is the slowest-yet-normal cervical dilation rate among primiparous women with spontaneous labor onset? J. Obstet. Gynecol. Neonatal. Nurs. 2010; 39, 361-9. 
http://wjst.wu.ac.th

[20] RBS Gallo, LS Santana, CHJ Ferreire, AC Marcolina, OB PoliNetto, G Duarte and SM Quintana. Massage reduced severity of pain during labor: A randomised trial. J. Physiother. 2013, 59, 109-16.

[21] BM Dossey. Nursing: Integral, Integrative, and Holistic-Local to Global. In: BM Dossey and L Keegan (Eds.). Holistic nursing: A handbook for practice. Burlington, 2013, p. 3-57.

[22] TF Najafi, RL Roudsari, and H Ebrahimipour. A historical review of the concept of labor support in technocratic, humanistic and holistic paradigms of childbirth. Electron. Physician. 2017; 9, 544651.

[23] S Adams, M Eberhand-Gran and A Eskild. Fear of childbirth and duration of labor: A study of 2,206 women with intended vaginal delivery. BJOG Int. J. Obstet. Gynaecol. 2012; 119, 1238-46.

[24] N Bol-bol-Haghighi, SZ Masoumi and F Kazemi. Effect of massage therapy on duration of labor: A randomized controlled trial. J. Clin. Diagn. Res. 2016; 10, 12-5.

[25] SU Erdogan and A Goker. Effects of low back massage on perceived birth pain and satisfaction. Completement Ther. Clin. 2017; 28, 169-75.

[26] SH Mortazavi, S Khaki, R Moradi, K Heidari and SFV Rahimparvar. Effects of massage therapy and presence of attendant on pain, anxiety and satisfaction during labor. Arch. Gynecol. Obstet. 2012; 286, 19-23.

[27] RMD Smyth, C Markham and T Dowswell. Amniotomy for shortening spontaneous labor. Cochrane Database Syst. Rev. 2013; 6, 1-84.

[28] OMC Vargens, ACV Silva and JM Progianti. Non-invasive nursing technologies for pain relief during childbirth: The Brazilian nurse midwives'view. Midwifery 2013; 29, e99-e106.

[29] ED Hodnett, S Gates, GJ Hofmeyr and C Sakala. Continuous support for women during childbirth. Cochrane Database Syst. Rev. 2013; 7, 1-113.

[30] JK Gupta, A Sood, GJ Hofmeyr and JP Vogel. Position in the 2nd stage of labor for women without epidural anaesthesia. Cochrane Database Syst. Rev. 2017; 5, 1-129.

[31] R Mander. Pain in Childbearing and Its Control: Key Issues for Midwives and Women. $2^{\text {nd }}$ ed. John Wiley \& Sons, Oxford, 2010, p. 12.

[32] A Lawrence, L Lewis, Hofmeyr and C Styles. Maternal positions and mobility during 1st stage labor. Cochrane Database Syst. Rev. 2013; 8, 1-158.

[33] P Sercekus and H Baskale. Effects of antenatal education on fear of childbirth, maternal selfefficacy and parental attachment. Midwifery 2016; 34, 166-72.

[34] A Safarzadeh, M Beigi, T Salehian, FKTTB Steh, SD Navabirigi and A Hosein. Effect of doula support on labor pain and outcomes in primiparous. J. Pain Relief 2012; 1, 1-4.

[35] M Handley, K MacGregor, D Schillinger, C Sharifi, S Wong and T Bodenheimer. Using action plans to help primary care patients adopt healthy behaviors: A descriptive study. J. Am. Board. Fam. Med. 2006; 19, 224-31.

[36] EG Eakin, SS Bull, KM Riley, MM Reeves, P McLaughlin and S Gutierrez. Resources for health: A primary-care-based diet and physical activity intervention targeting urban latinos with multiple chronic conditions. J. Health Psychol. 2007; 26, 392-400.

[37] YW Cheng, BL Shaffer, AS Bryant and AB Caughey. Length of the 1st stage of labor and associated perinatal outcomes in primiparous Women. Obstet. Anesth. Dig. 2012; 32, 21-9.

[38] K Melzer, Y Schutz, M Boulvain and B Kayser. Physical activity and pregnancy. Sport Med. 2010; 40, 493-507.

[39] JL Neal, NK Lowe, KL Ahijevych, TE Patrick, LA Cabbage and EJ Corwin. Active labor, duration and dilation rates among low-risk, primiparous women with spontaneous labor onset: A systematic review. J. Midwifery Womens Health 2010; 55, 308-18. 